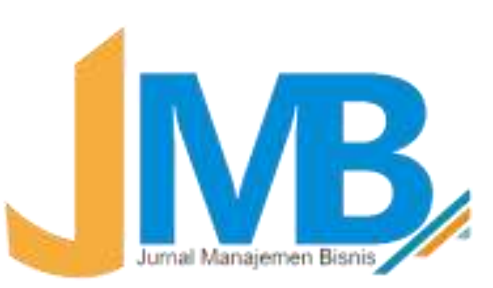

\title{
Performance of Merger and Acquisition, Director Experience, and Moderation Effects of Board Characteristics, Bidder Characteristics, and Type of Merger and Acquisition
}

\author{
Shindy Dwita Nuansari \\ Universitas Airlangga, Surabaya, Indonesia \\ Corresponding Author's Email: shindydwita01@gmail.com
}

Received:11-05-2020| Revision: 28-06-2020| Accepted:27-08-2020

To cite this document:

Nuansari, Shindy Dwita. (2020) "Performance of Merger and Acquisition, Director Experience, and Moderation Effects of Board Characteristics, Bidder Characteristics, and Type of Merger and Acquisition", Manajemen Bisnis, Vol. 10 No.1, pp.41-48, http://ejournal.umm.ac.id/index.php/jmb/article/view/10788

\begin{abstract}
This research focuses on influence of the experience of independent directors (two tier systems) on mergers acquisitions performance and considers several other factors as moderation. Purpose of this study was to determine the effect of the experience of independent directors to be moderated by board characteristics, bidder characteristics, and types of merger acquisitions on merger and acquisition performance and to be controlled by independent director's age. Research obtained from the company's financial and annual report data in 2009 - 2019. The dependent variable used in this study was merger and acquisition performance. Independent variable used in this study is independent director experience. Moderating variables in this are board characteristics, bidder characteristics, mergers and acquisitions types. The results of this study proves that the experience of director experience positively influences performance of merger and acquisition, board and bidder characteristics, type of merger and acquisition strengthen the positive influence of the experience of independent directors on merger and acquisition performance.
\end{abstract}

Keywords: independent director experience, board characteristics, merger and acquisition

\section{INTRODUCTION}

On December 21, 2018, the Indonesian Stock Exchange's plan to remove the obligation to hold an independent director's position for companies listed on the IDX had received approval from the Financial Services Authority (OJK) (Kurniawan, 2018). Independent director is part of the board of directors who have responsibility for company's daily activities. So the function of independent directors is to channel the aspirations of minority shareholders who buy through the Indonesia Stock Exchange (IDX) (Sikumbang, 2019). Based on this explanation, it can be concluded that the duties and responsibilities held by commissioners and independent directors are not the same. So, this can be something interesting to study, whether in fact the company still needs the role of an independent director or not. 
The experience of an independent director is something that has been experienced and borne by an independent director at a certain time and place. The Securities and Exchange Commission (SEC) also approved a new rule whereby companies are obliged to write explicitly on their proxy statements about the experience each independent company candidate has. The experience that is often highlighted by companies is merger acquisition performances owned by an independent director (Field \& Mkrtchyan, 2017). The experience of mergers and acquisitions is a very valuable experience for a director because independent directors who have a lot of mergers and acquisitions experience will significantly have the opportunity to get a chance on the board of directors in the following years (Harford \& Schonlau, 2013) .

Mergers and acquisitions are corporate strategies that can be applied by companies when companies want to expand operations. Companies that conduct mergers and acquisitions have several motives, namely tax considerations, manager's personal incentives, synergy, diversification and residual value (Brigham \& Houston, 2013). One of the company's performance is measured by looking at the operating performance of the company. Operating performance is a picture of how a company can create profits by utilizing the existing resources in the company properly. Good company operating performance can illustrate that the company has good information, so it will get a good response from investors. To get a good response from investors, the company must also be able to create good operating performance.

Performance of merger and acquisition is defined as company's ability to create profits from merger or acquisition events carried out by the company. Merger and acquisition performance can be measured by considering the company's operating performance a year before announcement date and a year after the merger and acquisition deals is completed (Field \& Mkrtchyan, 2017). Companies that have independent directors with a lot of experience in mergers and acquisitions will have positif effect on companies that will conduct mergers and acquisitions (Field \& Mkrtchyan, 2017). Companies with independent directors with experience of mergers and acquisitions can create better merger and acquisition performance compared to companies with independent directors who have less experience on mergers and acquisitions.

Mergers and acquisitions can also be effected by several factors including board characteristics, bidder characteristics, and mergers acquisitions type made by companies. Characteristics of a board with a proxy board size, the greater of the board size, make a better company's performance because it makes it easier for companies to get information so that companies can make decisions more precisely in mergers and acquisitions. The characteristics of bidders with a company size proxy, the greater size of the company, company will be more stable so that when companies want to do mergers and acquisitions, the company will get a better return. Horizontal mergers and acquisitions are one of the most effective types of mergers and acquisitions used to kill competitors and dominate the market, so that when a company engages in horizontal mergers and acquisitions with targets of companies that have the same industry as bidders, it will produce better mergers and acquisitions. Independent director's experience is an interesting phenomenon to study, because in Indonesia there is still rarely found research about effect of independent director's experience on mergers and acquisitions performance which are 
moderated by variable characteristics of boards and bidders, as well as the type of mergers and acquisitions.

\section{LITERATURE REVIEW}

According to Harford \& Schonlau (2013) independent director's experience in mergers and acquisitions can produce better returns on merger and acquisition activities than the ability or quality possessed by an independent director. One proxy of board characteristics is board size which is the number of boards of commissioners on the board of a company. The board of commissioners in the company has a role to oversee company's board of directors performance. Positive influence of the experience of independent directors on merger and acquisition performance was also strengthened by the characteristics of bidders. One proxy of bidder characteristics is the size of the company from the bidder company. Company's size can be defined as big picture of size of a company. Large companies are considered to have better characteristics and reputation when compared to smaller companies in terms of mergers and acquisitions. According to Poutziouris (2015) large companies are considered to have superior bargaining power when compared to small companies when they want to conduct mergers and acquisitions.

Types of mergers and acquisitions are also strengthen positive relationship between the experience of independent directors on the performance of mergers and acquisitions of companies. Mergers and acquisitions type is made between two or more companies engaged in the same industry called horizontal mergers or acquisitions. Horizontal type have the benefit of reducing business competition and increasing market power. Horizontal type are the best way to turn off competitors and dominate the market in their industry so as to produce a better company performance. Independent directors that has a lot of mergers and acquisitions experiences have proven to be more precise in determining merger and acquisition decisions compared to inexperienced independent directors (Custodio \& Metzger, 2013; Huang, Jiang, Lie \& Yang, 2014). Board size which is a proxy for board characteristics is strengthen the positive influence of the experience of independent directors in improving merger and acquisition performance. The influence of the experience of independent directors on performance of mergers and acquisitions is also moderated by the characteristics of bidders. According to Poutziouris (2015) company size which is a proxy of bidder characteristics can improve company performance. In addition, the experience of independent directors with merger and acquisition performance is also strengthened by the type of mergers and acquisitions. According to Zhou et al (2019) the type of mergers and acquisitions that have the greatest impact on the performance of mergers and acquisitions is the horizontal type. Based on this explanation, the hypothesis can be formulated as follows:

H1: The director independent experience has a positive effect on the mergers and acquisitions performance.

H2: Board characteristics strengthen the positive influence of independent director experience on mergers and acquisitions performance. 
H3: Bidder characteristics strengthen the positive influence of the independent directors experience on mergers and acquisitions performance.

H4: Types of mergers and acquisitions strengthen the positive influence of independent director experience on mergers and acquisitions performance.

\section{RESEARCH METHOD}

Measurements made in this study are based on the financial statements and annual reports of companies that conduct mergers and acquisitions in the period $2009-2019$, this study uses observations in a 10-year period referring to research conducted by Field \& Mkrtchyan, 2017. Observed companies in this study, in a period of 10 years there were several companies that did mergers and acquisitions only once, but there were those that did mergers and acquisitions even up to five times. This study examines the influence and significance of the experience of the independent director as an independent variable on merger and acquisition performance as the dependent variable, and board characteristics , bidder characteristics, merger and acquisition types as moderation variables. This research focuses on testing hypotheses with statistical analysis tools and measured data so as to produce conclusions that can be generalized. The dependent variable is measured by:

$$
\operatorname{ROA}_{i, t}=\frac{\text { EBIT }_{i, t}}{\text { TotalAset }_{i, t}}
$$

The results of ROA are grouped into five quintiles, where quintiles $1(<-5)$, quintiles $2(-5$ to 0 ), quintiles $3(0.01-5)$, quintiles $4(5.1-10)$, and quintiles 5 ( $>10)$. The independent variable uses the experience of the independent director as measured by summing up the experience of mergers and acquisitions that have been carried out by independent directors in the previous period. Then the total experience of independent directors is grouped into five quintiles, namely quintiles $1(0)$, quintiles 2 (1-3), quintiles 3 (4-5), quintiles 4 (6-9), and quintiles 5 (> 10).

Proxy of board characteristics used is board size measured by counting the number of boards of commissioners in companies that conduct mergers and acquisitions. Then group them into five quintiles, namely quintiles 1 (1-3), quintiles 2 (4-6), quintiles 3 (7-9), quintiles 4 (1012), quintiles 5 (> 12). Proxy of bidder characteristics used is firm size measured by the following formula:

$$
\operatorname{size}_{i, t}=\operatorname{Ln}(\text { totalassets })_{i, t}
$$

Types of mergers and acquisitions in this study use a dummy variable where for the type of horizontal mergers and acquisitions are given the number 1, and besides that will be given the number 0 . The control variable uses independent director's age as measured by the age of an independent director when an independent director is in the company of a merger and acquisition. The age of independent directors is then grouped into two groups based on the age category according to WHO (World Health Organization) namely group 1 of the youth age category (18-65 years) and group 2 for the middle age category (66-79 years). 
Moderated regression analysis (MRA) is used in this study. Analysis model in this study was formulated as follows:

Analysis Model 1

$$
R O A_{i, t}=\beta_{0}+\beta_{1} \exp _{i, t}+\beta_{2} a g e_{i, t}+e_{i, t}
$$

Analysis Model 2

$$
R O A_{i, t}=\beta_{0}+\beta_{1} \exp _{i, t}+\beta_{2} b s_{i, t}+\beta_{3} \exp _{i, t} * b s_{i, t}+\beta_{4} a g e_{i, t}+e_{i, t}
$$

Analysis Model 3

$$
R O A_{i, t}=\beta_{0}+\beta_{1} \exp _{i, t}+\beta_{2} \operatorname{size}_{i, t}+\beta_{3} \exp _{i, t} * \operatorname{size}_{i, t}+\beta_{4} a g e_{i, t}+e_{i, t}
$$

Analysis Model 4

$R O A_{i, t}=\beta_{0}+\beta_{1} \exp _{i, t}+\beta_{2}$ tipe $_{i, t}+\beta_{3} \exp _{i, t} * \operatorname{tipe}_{i, t}+\beta_{4} a g e_{i, t}+e_{i, t}$

While $\beta_{0}$ is a constant, $\beta_{1} \ldots \beta_{4}$ is the regression coefficient, $R O A_{i, t}$ is the acquisition performance, $\exp _{i, t}$ is the experience of the independent director, $b s_{i, t}$ is the board size of

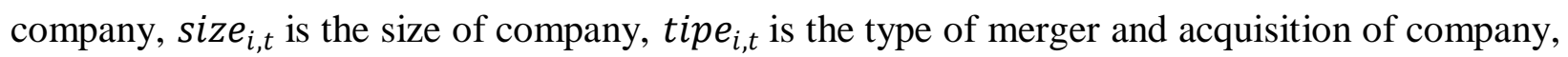
$a g e_{i, t}$ is the age of the independent director of company, $\exp _{i, t} * b s_{i, t}$ is the interaction between the experience of the director and board size of company, $\exp _{i, t} * \operatorname{size}_{i, t}$ is the interaction between the experience of independent directors and company size, $\exp _{i, t} *$ tipe $_{i, t}$ is the interaction between the experience of independent directors and the type of merger and acquisition of company, $e_{i, t}$ is the error or residual value of company.

\section{RESULT AND DISCUSSION}

Table 1 shows that the director's experience variable (exp) has a significant positive coefficient of 0.666 which means that increasing the experience of an independent director of one unit will increase the merger and acquisition performance of 0.666 . The significance value of the director's experience variable is less than 0.01 , which is equal to 0,000 . It can be concluded that $H_{0}$ is rejected and $H_{1}$ is accepted.

Table 1. Result of Multiple Linear Regression Analysis

\begin{tabular}{ccccc}
\hline \multirow{2}{*}{ Variable } & \multicolumn{3}{c}{ ROA } \\
\cline { 2 - 5 } & 1 & 2 & 3 & 4 \\
\hline \multirow{2}{*}{ Intercept } & 0,149 & $-0,091$ & $-0,030$ & 0,146 \\
& $(0,715)$ & $(0,824)$ & $(0,943)$ & $(0,694)$ \\
\hline \multirow{2}{*}{ Exp } & $0,666^{* * *}$ & $0,326^{*}$ & $0,376^{* * *}$ & $0,475^{* * *}$ \\
& $(0,000)$ & $(0,082)$ & $(0,005)$ & $(0,000)$ \\
\hline \multirow{2}{*}{ Bs } & & $0,125^{* *}$ & \\
\end{tabular}




\begin{tabular}{|c|c|c|c|c|}
\hline \multirow{2}{*}{ Variable } & \multicolumn{4}{|c|}{ ROA } \\
\hline & 1 & 2 & 3 & 4 \\
\hline exp*bs & & $\begin{array}{c}0,182 * * \\
(0,029)\end{array}$ & & \\
\hline Size & & & $\begin{array}{c}0,196^{* *} \\
(0,049)\end{array}$ & \\
\hline exp*size & & & $\begin{array}{c}0,061 \text { ** } \\
(0,043)\end{array}$ & \\
\hline tipe & & & & $\begin{array}{c}0,216^{* * *} \\
(0,031)\end{array}$ \\
\hline exp*tipe & & & & $\begin{array}{c}0,206^{* *} \\
(0,027)\end{array}$ \\
\hline age & $\begin{array}{c}0,769 * * * \\
(0,009)\end{array}$ & $\begin{array}{c}0,742 * * * \\
(0,008)\end{array}$ & $\begin{array}{c}0,737 * * * \\
(0,007)\end{array}$ & $\begin{array}{c}0,589 * * \\
(0,028)\end{array}$ \\
\hline R-Square & 0,395 & 0,471 & 0,497 & 0,421 \\
\hline F-Statistic & $\begin{array}{c}23,833 * * * \\
(0,000)\end{array}$ & $\begin{array}{c}15,976 * * * \\
(0,000)\end{array}$ & $\begin{array}{c}17,530 * * * \\
(0,000)\end{array}$ & $\begin{array}{c}16,001 * * * \\
(0,000)\end{array}$ \\
\hline
\end{tabular}

Source : Results of data processing IBM SPSS statistics 25 for windows

According to the SGP No.7 / 2007 Statement of Good Practice an independent director is a person who has no relationship with the related company, or whose officials may interfere with, or are deemed to interfere, in carrying out business valuations. Based on this definition it can be concluded that 'independent' refers to independent of management, because the independent director must provide input to management, when management makes executive decisions within the company, as an independent party that controls for managing the company. Independent director experince has a significant positive effect on mergers and acquisitions performance of companies, which means that more experience of mergers and acquisitions owned by independent directors can lead to better merger and acquisition performance. The results of this study are in line with research conducted by McDonald, Westphal, \& Graebner (2008), Haford \& Schonlau (2013), Field \& Mkrtchyan (2017) which states that the director's experience in conducting mergers and acquisitions has a significant positive effect on the rate of return from mergers and acquisition.

Variable characteristics of the board (exp * bs) have a significant positive coefficient of 0.182 . The significance value of the moderating variable characteristics of the board is less than 0.05 which is 0.029 . It can be concluded that $H_{0}$ is rejected and $H_{2}$ is accepted. The results of the study are in line with the idea that a larger board size will improve company performance. Larger board size can have information a larger collective that can later result in better company performance.

The moderating variable of bidder characteristics has a positive coefficient of 0.061 and a significance value of $\alpha$ less than 0.05 , which is 0.043 , the bidder characteristics measured by company size are strengthen the positive influence of the experience of independent directors on performance company mergers and acquisitions. These results indicate that $H_{0}$ is rejected and $\mathrm{H}_{3}$ is accepted. This shows that the larger the size of the company, the merger and acquisition performance of the company will also increase. Moderating variable of the type of merger 
acquisition (exp * type) has a regression coefficient of 0.206 . The significance value is smaller than the tolerance value $\alpha=0.05(0.027<0.05)$, so that $H_{0}$ is rejected and $H_{4}$ is accepted. It is meaning that when a company takes over a target company with the same industry as a bidder company, the company can produce better returns on mergers and acquisitions when compared to companies different target industry from bidder companies.

\section{CONCLUSION}

If companies that conduct mergers and acquisitions are able to utilize the existence of independent directors well, one of them is by looking at the experience owned by independent directors, the company will be able to create better merger and acquisition performance. Based on the results of this study the experience of an independent director has a significant positive effect on the performance of mergers and acquisitions. Characteristics of the board, bidders, and the type of merger acquisition become variables that can strengthen the positive relationship between the experience of independent directors and the merger and acquisition performance of the company. This is evidenced by the results of the coefficient and a significant positive significance value. So it can be concluded that the characteristics of the board, bidders, and the type of acquisition merger can moderate the influence of the independent director's experience variable on merger and acquisition performance.

At present, existence of independent directors is no longer required in listed companies, but this information can be used as a reference for companies in the appointment of independent directors, especially for companies that want to do mergers and acquisitions. also other variables that are able to strengthen the performance results of mergers and acquisitions are also important for companies, especially those who want to do mergers and acquisitions. This research has been carried out according to scientific procedures, however in this study still has some limitations, namely the factors that moderate the relationship between the experience of independent directors with merger and acquisition performance consisting of only three variables, namely the characteristics of the board, bidders, and the type of merger acquisition while still many factors which can be used in this study.

\section{REFERENCES}

Aisyah, S. (2012). Perkembangan dan Konsep Dasar Pengembangan Anak Usia Dini. Tangerang: UT.

Brigham, E. F., \& Houston, J. F. (2013). Dasar-dasar Manajemen Keuangan. Jakarta: Salemba Empat.

Cai, Y., \& Sevilir, M. (2012). Board Connections and M\&A Transactions. Journal of Financial Economics, 327-349.

Custodio, C., \& Metzger, D. (2013). How Do CEOs Matter? The Effect of Industry Expertise on Acquisition Return. Review of Financial Studies, 2008-2047.

Field, L. C., \& Mkrtchyan, A. (2017). The Effect of Director Experience on Acquisition Performance. Journal of Financial Economics, 12;32, 1-24. 
Harford, J., \& Schonlau, R. (2013). Does the director labour market offer expost setting-up for CEOs? The case of acquisition. Journal of Financial Economics., 110. 18-36.

Huang, Q., Jiang, F., Lie, E., \& Yang, K. (2014). The Role of Invesment Banker Directors in M\&A : Can Expert Help? Journal of Financial Economics, 269-286.

Huybrechts, J., Voordeckers, W., \& Lybaert, N. (2012). Entrepreneurial risk taking of private family firms: The influence of a nonfamily CEO and the moderating effect of CEO tenure. Family Business Review, 26, 161-179.

Kurniawan, W. (2019). OJK Restui Penghapusan Kewajiban Punya Jabatan Direktur Independen. Jakarta: kontan.co.id.

Poutziouris, P.,Savva, C., Hadjielias, E. (2015). Family Involvement and Firm Performance : Evidence from UK Listed Firms.6 (1) : 14-32.

Sikumbang, I. R. (2019). Menakar Efek Hilangnya Dirketur Independen dari Jajaran Manajemen Emiten. Jakarta: Kompasiana.com.

Zhou, B., Dutta, S., and Zhu, P. (2019). C CEO Tenure and Mergers and Acquisitions. Finance Research

Letters 
